\title{
Specification a model for study of symbolic processualism
}

\author{
García Lirios, Cruz \\ Universidad Autónoma del Estado de México, México \\ garcialirios@yahoo.com
}

\begin{abstract}
Gross mode, the symbolic processualism refers to four phases of social change: 1) vicissitude, 2) conflict, 3) resignification and 4) building. The objective of the present work was to establish the procedural discursive networks around the coffee entrepreneurship in informants of a locality in the center of Mexico. An exploratory, transversal and interpretative study was carried out with an intentional selection of native informants. The findings show differences among the participants with respect to the categories of decadence and prosperity. Research lines concerning the production and marketing cycle of coffee in relation to the cycle of symbolic representation are warned in order to interpret scenarios of local development.
\end{abstract}

Keywords: Migration; entrepreneurship; coffee growing; processualism; remittances;

Resumen - A groso modo, el procesualismo simbólico se refiere a cuatro fases de cambio social: 1) vicisitud, 2) conflicto, 3) resignificación y 4) construcción. El objetivo del presente trabajo fue establecer las redes discursivas procesales en torno al emprendimiento cafetero en informantes de una localidad del centro de México. Se realizó un estudio exploratorio, transversal e interpretativo con una selección intencional de informantes nativos. Los resultados muestran diferencias entre los participantes con respecto a las categorías de decadencia y prosperidad. Se advierten líneas de investigación sobre el ciclo de producción y comercialización del café en relación con el ciclo de representación simbólica para interpretar escenarios de desarrollo local.

Palabras Clave: Migración; Emprendimiento; Cultivo de café; Procesualismo; Remesas;

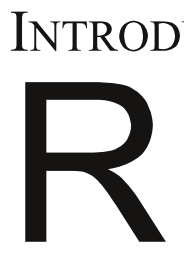

emittances, coffee growing, and speeches, are imaginary trinomial to establish the contribution of remittances and coffee to local development. Precisely, the objective of the present study was to in-
Interconectando Saberes, 2020

ISSN: 2448-8704
Fecha de Recepción: 12 de diciembre de 2019

Fecha de Aceptación: 28 de febrero de 2020

Fecha de Publicación: 09 de marzo de 2020 
terpret and understand the discourses and narratives surrounding coffee growing and entrepreneurship as figurative nuclei of local development. An exploratory, transversal and interpretative study was carried out with three informants considered key for the study community. Based on in-depth interviews and life stories, evocations relating to $\mathrm{mi}-$ gration and entrepreneurship were established. The meanings warn that opportunities are the key to understanding local narratives about their endogenous development.

Informants were interviewed in the facilities of the local public library, after telephone contact and presentation of the project's objectives, as well as the written guarantee that their answers would not affect their economic, political, social or work status. He offered to disseminate the findings through his email.

The information was processed in the qualitative data analysis software (QDA by its acronym in English version 4.0). Matrix of discourse analysis and narrative networks were established around the catego- ries of development, migration, coffee growing and entrepreneurship. From the technique of symbolic processualism the statements related to the categories in question were weighted. The coding of the information was made based on the frequencies or order of appearance in the statements of the informants.

The project is part of the division of social sciences, discipline of social work, area of socioeconomic studies, but also includes premises of cultural anthropology, solidarity economy and community psychology. The project was carried out thanks to the financing of the National Autonomous University of Mexico, General Directorate for Academic Personnel Affairs, Support Program for Research Projects and Technological Innovation.

\section{REMITTANCES, COFFEE}

\section{GROWING AND SPEECHES}

Social exclusion is based on the denial of access to equal opportunities established by relations between individuals, groups or regimes. The underlying inequalities are produced and reproduced as domination expands through power 
or influence. In addition, it supposes the fracture of citizenship as it is associated with poverty (Osorio, 2012).

A direct consequence of social exclusion is the migratory identity indicated by discourses and lifestyles that provide experiences that by degree of significance reveal and indicate the impact of a phenomenon on the dynamics of a community (Piña, 2012).

Assuming that public spending has increased while concentrating on an increase in GDP that went from $35 \%$ to $45 \%$ in Europe and from $9 \%$ to $20 \%$ in Latin America, it is an instrument to reduce unemployment, by linking with the population dynamics this public policy seems insufficient for $47 \%$ of families that are two-parent. That is to say, the public security and the rectory of the State seem to be extinguished in the new neoliberal model, although the remittances have reached $29 \%$ of the GDP in Haiti, between $15 \%$ and $27 \%$ of the Mexican GDP and Argentina with 2\% (Arteaga, 2012b).
Because remittances activate a part of the economy, the quality of social services is reflected in institutional budgets, since in the case of retirees around $40 \%$ with less than 70 years old, they have a pension, Chile is the country with more members Funds Retirement Savings coverage of $63 \%$ and the Dominican Republic last place with $1.7 \%$, while Mexico has 35000 members, but only $30 \%$ are active in your quote. In contrast, Chile has 7,000 members, 4,000 taxpayers, and $59 \%$ belongs to the Economically Active Population (Campana, 2014).

The data show that there is a link between the flows of human and migratory capital, although prosperity implies an intense relationship between the right to private property and the right to the benefit of income. In this sense, there are three capitals that regulate conflicts of interest and from them studies of the state of knowledge are framed (Arteaga, 2012c).

It is about the physical capital that supposes groups linked to objects and / or purposes of transformation and distribution. In this sense, the skills and knowledge are 
essential for linking physical and human capital which refers to personal skills that, when combined with the capabilities of other individuals or groups, then configure networks cooperation (Ondarrieta, 2012).

In this way, entrepreneurship is the result of the convergence of capital, physical, human and social from which trust, commitment and cooperation are established.

\section{Processualism Cultural SOCIOPOLITICAL}

The study of remittances and coffee production, due to its degree of intensity in social groups and sectors, supposes a sociopolitical approach because it is framed in the context of the transformation of the State (López, 2012).

It is a study of civic-moral supremacy that guarantees the legitimacy of a political system before the civil processualism of pod and influence. The prevalence of a vision of politicized world and the trend of an order Socialized are indicative of processualism symbolic phenomenon (Giosso, 2013).
This system shapes spirit, morals, customs, habitus, ethics and rationalities in four phases; 1) breaking of norms, 2) identity crisis, 3) conflict between the actors involved and 4) pacification and reconciliation based on public agreements and agreements.

In authoritarian and totalitarian regimes, although it can be applied to democracies, the State propagates symbols to legitimize it in the face of citizenship; it is about ceremonies, architectures and myths in which the political culture is built from the apparent stability that the regime diffuses in the media. This political culture reproduces the fields of power and influence through perceptions, beliefs and attitudes that polarize society, but end up reconciling it with the option that the regime represents (Cano, 2012).

It is as well as the symbolic processualism is product of the four exposed phases, but its sociopolitical character is acquired in the moment in which the citizenship attributes its future to the public security that the State offers, or, to the loss of its rectory (Arteaga, 2012a). 
From the four phases exposed it is possible to notice that remittances and coffee farming can be analyzed as normative, critical, conflictive and restorative symbols that in the discourses of the informants may or may not be present, but in a personal or collective life context emerge meanings about the power and influence that the authorities propagate hoping to activate the socio-political process.

\section{SYMBOLIZATIONS OF}

\section{REMITTANCES AND COFFEE}

\section{AROUND LOCAL DEVELOPMENT}

The symbolic processualism related to Local Development lies in the significance of migration, mainly remittances and their investment in the production and marketing of coffee.

In the case of established traders, this proceduralism legitimizes a change of administration on the eve of the elections:

"We trusted a lot in this president, but later we realized that he lacked initiative and now we hope that the one who comes will solve the problem of employment and investment that Xilitla requires to return to what it was and that people can trust again in the government "(Interview with tenant of Xilitla).

The processualism from the perspective of the merchant is a discharge of responsibility to the municipal president, referring to other past or future administrations, it is considered that the origin of the problems emanating from the power of the rulers to reconcile interests and settle disputes arising from a crisis of credibility.

"This administration does not know what to do when it comes to activating the trade. I worked in previous years to manage the supports to the commerce, now this president only has me as an informant of the needs of the tenants "(Interview with tenant of Xilitla).

In this symbolic processualism, migration is an effect of unemployment and this in turn is caused by the inability of the president to manage the supports to trade, the main economic activity of the demarcation. 
However, the relationship between remittances and entrepreneurship seems to corroborate the symbolization that the merchant performs with respect to those who must take the initiative to reactivate sales and thereby employment.

"The government supported its relatives and the others left us without the financing we needed to start over again. This president procured his family and the rest of Xilitla denied us the right to ask for help "(Interview with tenant of Xilitla).

The symbolic processualism of the tenant follows the logic of breaking rules, economic crisis, conflicts between authorities and the governed, but apparently the political legitimacy of the current regime has not yet been established.

In contrast, migrant processualism seems to follow a logic of prosperity as they attribute the crisis to natural disasters:

"Xilitla has always been a place of a lot of rain. There have been landslides and when the rains do not stop, the coffee crops and other things that we sow are lost. Therefore, people are left without work and have to go to the United States, there they have a family and they decide to leave for a while until they collect money and return to Xilitla."

Regarding the conflict that the tenant attributes to the president's inability to break the rules and the current employment crisis, the migrant rather observes that the government is conciliatory with those who demand economic support or financing for the cultivation of coffee and those who do not wish to invest that money in a paid activity.

"In Xilitla there are two types of people; those who work coffee and those who are engaged in trade, but more who cultivate, deserve the support of the president, but who only want to sell, without producing or getting up early, then they do not deserve the president to support them or receive them, for what? If they have merchandise right now and then what they earn, they spend it to drink."

The crisis is symbolized by the migrant as a problem of personal order that not even the economic support would serve to undertake a business or other remunerated activity. 
Therefore, the conflict is for the migrant, an internal problem, attributable to the individual capacities since, if the opportunities are provided by the authorities, then following the migrant's proceduralism, it depends on the people to take advantage or not of that opportunity.

Unlike the tenant who sees in unemployment the origin of all the problems, that even at a given moment exceed their individual capacities, the migrant warns that the problem is due to the lack of initiative or capacity of those who permanently reside.

"I come to Xilitla whenever I can, but this year I've come three times and I realize that people are still the same, waiting for the government to give them help or that their relatives who are in the United States send them money to go by, that money is a lot and they can save "(Interview with migrant resident in Xilitla)

Finally, the political culture that the migrant expressed with respect to the tenant, is rather confidence in the municipal president since, if they compare it with that of their community, then they end up accepting the management failures whenever in the crops of coffee continue to have a job opportunity.

"Before arriving in Xilitla, there was no work in my community and now we are still out of work, but they do not warn us that in Xilitla they needed to grow coffee, sell and load, now they pay us because before it was with the same product "(Interview with migrant resident in Xilitla)

The sociopolitical processualism seems to be present in the migrant, because employment opportunities have been significant for them. In this sense, the migrant associates unemployment or employment with municipal management as well as the tenant, but the difference between the two is that, for the tenant, the president is only an intermediary of the economic and labor system, in the case of the migrant, job opportunities emanate from the government, even if they are coffee entrepreneurs who hire them, they attribute the job to the management of the municipality. 
That is why for the migrant political norms are superimposed on the economic or labor standards, in contrast, for the tenant the lack of financing affects these same migrants who are employed in the established stores.

These assessments are far from those declared by the official. From their position, labor regulations are regulated by the municipality in an efficient way that even provide employment to migrants and not only to natives, but the fact that they decide to migrate is not due to the incompetence or inability of the municipality, but rather to the family ties they have with the United States, from where the greatest tourist demand comes from.

"Here in the administration we have facilitated the credits that the federal government has assigned to Xilitla as a magical town, most of the loans have been recovered and that speaks well of the community because in that way they finance us again public and social spending At the same time, it guarantees investment funds for trade planning, employment regulation and the promotion of tourism. It is true that people migrate, but it is because they have relatives in the United States. Even our tourist offer is promoted there and as a result of this propaganda we have a wave of visitors every year "(Interview with Xilitla official)

The socio-political processualism of the official seems to legitimize coffee and tourism promotion policies to the extent that the results reach the budgeted objectives. The planning of public resources is presented as an instrument of management and governability that by the results achieved make evident the continuity of the municipality's promotion as a magical town, the intensification of trade and the diffusion of tourist attractions, however the public administration recognizes that natural disasters and environmental catastrophes are pending signatures in terms of civil protection.

"Last year the rains intensified and the measures to protect the population were insufficient, the climate is like this and we can only prepare for the shelter of the population in shelters that the municipality has created in order to establish a monitoring system for the population that lives in ravines or near the river, but this 
government has been concerned about giving them shelter and sustenance while the contingency ends "(Interview with Xilitla official)

\section{Processualism sociopolitical,} from the perspective of official, public safety is more than in disaster prevention; floods or droughts that impact the economy, production, employment and trade.

The processualism of the official lies in the management of risks as a principle of governance and political stability before the rule of irregular human settlements, the excessive growth of the population in risk areas, the subsequent crisis of public health, conflicts over the supply of food and federal support, but while these environmental problems do not arise, the achievements of the current government permeate the official's speech in the same way that the migrant recognizes employment opportunities.

It is a legitimizing predecimalization of coffee and ecotourism development policies as standards of local development, but the discre- tionarily of fiscal incentives or economic support to small coffee growers and microentrepreneurs distills a clientelist and elitist processualism that excludes only small merchants and small businesses.

In short, the sociopolitical processualism seems to show that before ecological crises, the municipal government has a protocol of action that focuses on civil protection and support for those who are closest to their policies to the detriment of tenants and merchants who seem to notice their exclusion in the distribution of financing.

However, the sociopolitical processualism takes on special relevance at the moment when faced with a crisis or conflict, the municipal authority is designated as responsible for mediating between the parties until reaching agreements that benefit the municipality, but at the same time the surrounding localities dependent on the Trade and employment opportunities celebrate the political decisions of the demarcation. 
It is a socio-political processualism that is not exclusive to the locality and has been extended to the other demarcations that share with Xilitla the entrepreneurial spirit or at least the migrant spirit.

It should be noted in this sense that social entrepreneurship has its sociohistorical roots in the construction of roads and the ecotourism park, public administrations have taken advantage of this and this is not only reflected in the speeches of the interviewees, but also it is possible to warn the investment and public spending that the city has allocated to the repair of public areas.

However, sociopolitical processualism is not only the exclusive property of the authorities, it is also disseminated to the public as they perceive benefits and attribute them to municipal management.

Processualism sociopolitical has a variant in the mystical art that was implemented in its tourist attractions and operates as offering experiences not only for migrants but for tourists from different latitudes.

\section{FinAL CONSIDERATIONS}

The contribution of the present work to the state of knowledge lies in; 1) the collection of information concerning the symbolic predecimalization of informants linked to migration, remittances, entrepreneurship and coffee production; 2) the processing of discourses and narratives around the categories mentioned: 3 ) the interpretation of symbols, meanings and meanings centered on the cycle of hegemony and coffee crisis as a factor of local development.

In relation to the theoretical, conceptual and empirical frameworks, which warn that social change lies in selective, cyclical, dispositional and conflictive processes, the present work warns that local change is rather due to a process of resignification of entrepreneurship in which The State and the private initiative are complementary actors of the proposals and civil initiatives. 
Due to the type of exploratory and interpretative study, as well as the intentional selection of the sample, it is necessary to: a) construct measurement instruments for the study categories; b) weight the trajectories of relationships between the variables derived from the categories; c) anticipate scenarios of symbolic process.

\section{REFERENCES}

Arteaga, C. (2012). The mechanism of the veil of institutional ignorance. In C. Arteaga (coord.). Public policies and citizen participation. A focus from social work. (pp. 15-23). Mexico: UNAM-ENTTS

Arteaga, C. (2012). Citizen participation An absence? A study in Mexico City. in C. Arteaga (coord.). Public policies and citizen participation. A focus from social work. (pp. 87-139). Mexico: UNAMENTS

Arteaga, C. (2012). Citizen participation as an alternative to poverty. In L. Cano (coord.). The social impact of poverty. Discussion and analysis. (pp. 27-36). Mexico: UNAM-ENTS

Campana, M. (2014). From the social state to the neoliberal state. A new social pact in our America. Social Perspectives, 16 (1), 9-30
Cano, L. (2012). Reflections of poverty in Mexico. In L. Cano (coord.). The social impact of poverty. Discussion and analysis. (pp. 25-35). Mexico: UNAM-ENTS

Giosso, C. (2013). The social economy from three perspectives: third sector, non-governmental organizations and non-profit entities. Trends and Challenges, 18 (1), 143-158

López, M. (2012). Poverty: a multifaceted and intervention scenario for social work. In L. Cano (coord.). The social impact of poverty. Discussion and analysis. (pp. 191-203). Mexico: UNAM-ENTS Ondarrieta, M. (2012). Education and employment as essential factors in the fight against poverty. In L. Cano (coord.). The social impact of poverty. Discussion and analysis. (pp. 91-104). Mexico: UNAM-ENTS

Osorio, J. (2012). State, biopower and exclusion. Analysis from the logic of capital. Barcelona:

Anthropos.

Piña, A. (2012). Citizen participation and urban poverty. In L. Cano (coord.). The social impact of poverty. Discussion and analysis. (pp. 11-26). Mexico: UNAM-ENTS 